Instructions for authors, subscriptions and further details:

http://ijep.hipatiapress.com

\title{
Self-regulation of Behavior: Students Versus Other Adults
}

Jitka Jakesova, Peter Gavora, Jan Kalenda ${ }^{1}$

1) Tomas Bata University in Zlín, Czech Republic

Date of publication: February $24^{\text {th }}, 2016$

Edition period: February 2016 - June 2016

To cite this article: Jakesova, J., Gavora, P., Kalenda, J. (2016). Selfregulation of behavior: Students versus other adults. International Journal of Educational Psychology, 5(1), 56-79. doi: 10.17583/ijep.2016.1661

To link this article: http://dx.doi.org/10.17583/ijep.2016.1661

\section{PLEASE SCROLL DOWN FOR ARTICLE}

The terms and conditions of use are related to the Open Journal System and to Creative Commons Attribution License (CC-BY). 


\section{Self-regulation of Behavior: Students Versus Other Adults}

Jitka Jakesova, Peter Gavora, Jan Kalenda

Tomas Bata University in Zlín

\section{Abstract}

The objective of this research is to compare self-regulation of behaviour of two Czech samples. The first one was the representative sample of Czech adults that consisted of 1060 respondents. The second sample was university students and consisted of 1244 respondents. The measuring tool was an adapted Self-Regulation Questionnaire of which two dimensions were used: Goal Orientation and Impulsivity. The findings showed no statistically significant differences between the two samples in either of the dimensions. Goal Orientation scores were higher than Impulsivity scores, which was in line with our assumptions. There were no statistically significant differences in Goal Orientation scores between genders, with the exception of prevalence of females in the student sample. Age appeared to be an important factor that affects scores in Goal Orientation in both samples, while in Impulsivity it only differentiated among the students. The level of education proved to be an important factor that differentiates among those with high and low impulsivity rather than in goal orientation.

Keywords: self-regulation of behaviour, psychometric study, goal-orientation, impulsivity. 


\section{Auto-regulación de la Conducta: Estudiantes versus Otros Adultos}

Jitka Jakesova, Peter Gavora, Jan Kalenda

Tomas Bata University

\section{Resumen}

El objetivo de esta investigación es comparar la autorregulación del comportamiento de dos muestras checas. La primera fue representativa de adultos Checos, de 1060 encuestados y, la segunda, fue de estudiantes universitarios y constaba de 1244 encuestados. La herramienta de medición fue un cuestionario adaptado de Autorregulación del que se utilizaron dos dimensiones: Orientación de Meta e Impulsividad. Los resultados no mostraron diferencias estadísticamente significativas entre las dos muestras en ninguna de las dimensiones. Los resultados de Orientación de Meta fueron mayores que los de Impulsividad, en consonancia con nuestra hipótesis. No hubo diferencias estadísticamente significativas en las puntuaciones en Orientación de Meta entre géneros, con la excepción de prevalencia de estudiantes de sexo femenino en la muestra de estudiantes. La edad apareció como factor importante que afecta las puntuaciones en la Orientación de Meta en ambas muestras, mientras que para la Impulsividad sólo diferenció entre los estudiantes. El nivel de educación resultó ser un factor importante que distingue a personas con alta y baja impulsividad en vez de en orientación de meta.

Pallabras clave: autorregulación de la conducta, estudio psicométrico, orientación de logro, impulsividad 
$\circlearrowleft$

elf-regulation is an important personal characteristic which strongly affects one's actions and behaviour. It is often described as the ability to develop, implement, and maintain planned behaviour in order to achieve personal goals (Brown, Miller, \& Lawendowski, 1999). Self-regulation can be seen as the voluntary control of attentional, emotional, and behavioural impulses in the service of personally valued goals and standards (Duckworth \& Carlson, 2015). Generally, self-regulation is claimed to be the basic ability of the individual to regulate oneself in relation to the environment and personal goals. In doing this, the individual overcomes the discrepancy between one's expectations and the reality (Brown, Miller, \& Lawendowski, 1999; Carver \& Scheier, 2011; de Ritter \& de Witt, 2006; Hoyle, 2010; Zimmerman, 2000).

\section{Self-Regulation Research}

\section{The Scope of Self-regulation Areas}

In the last fifty years, elaboration of the theory of self-regulation has been in the focus of activities in many scientific fields. Self-regulation has been investigated in educational psychology, social cognitive theory and adjacent disciplines. Considerable research of self-regulation has been conducted also in health psychology on stress and coping behaviour. For instance, Carey, Carey, Carnrike and Meisler (1990) examined the relationship between learned resourcefulness and two common addictive behaviours, e.g., drinking and smoking. In the research male and female college students completed a series of research instruments, such as the Self-Control Schedule, the Quantity-Frequency-Variability questionnaire, and a smoking history form. Overall, the results provided correlational support for the notion that learned resourcefulness may protect young adults against substance abuse. Chassin and De Lucia (1996) have associated a variety of serious health risks with adolescent drinking, including the three leading causes of death among adolescence groups (i.e., unintentional injuries, homicide, and suicide) as well as unsafe sexual behaviour. Risk factors for adolescent drinking encompass, inter alia, alcohol availability and some 
personality traits, particularly those indicating low self-regulation, and pleasurable beliefs about alcohol effects.

The predictions, derived from the self-regulation model, about variables moderating the relationship between the forms of substance (alcohol, tobacco, and marijuana) and problems associated with the use were tested by Wills, Sandy and Yaeger (2002). Likewise, the study of work motivation theories and related area of procrastination enhanced the understanding of self-regulation issues (Eerde, 2000; Senécal \& Vallerand, 1995; Motiea, Heidaria, \& Sadeghic, 2012).

There has been vast research conducted of the role played by selfregulation in academic learning. For instance, Veenstra, Lindenberg, Tinga and Ormel (2010) documented that low self-regulation of behaviour is associated with students' drop-out and truancy. There is also some evidence that self-regulation predicts course grades. This prediction is stronger than that of standardized achievement test scores. Duckworth, Quinn, and Tsukayama (2012) found in middle school students, who were followed longitudinally, that self-control predicted changes in grades over time better than did IQ. Nota, Soresi and Zimmerman (2004) provided evidence that the cognitive self-regulation strategies proved to be a significant predictor of the students' course grades in Italian (mother tongue), mathematics, and technical subjects in high school and in their subsequent average course grades and examinations passed at the university.

\section{Components of Self-regulation}

The self-regulation construct proves to fit well with well-known phenomena of human behaviour, such as control of attention (Carver \& Scheier, 2011), control processes, self-organization (Carver \& Scheier, 2002), and goal disengagement (Wrosch et al., 2003).

There is a large variability in the theoretical constructs of self-regulation of behaviour; however, the theories share two common characteristics: (1) self-regulation is conceived to be a dynamic motivational system related to goal-setting and goal attaining strategies; (2) it is connected with the control and regulation of emotions and impulsivity, which accompany goal 
attaining. Self-regulation, in turn, affects the motivational system of the individual (Cameron \& Leventhal, 2003).

There is extensive literature describing goal-setting and aim-directedness as important components of self-regulation (Austin \& Vancouver, 1996; Carver \& Scheier, 1998; Carver, 2004; de Ridder \& de Wit, 2006; Elliott 2008; Mischel, Cantor, \& Feldman, 1998; Schunk \& Zimmerman, 1998; Schwarzer, 2001; Zimmerman, 2000). For instance, Carver and Scheier (2011) maintain that "goals always constitute key components of selfregulation of behaviour" (p.4). Emotions that accompany actions create simultaneous feedback about the adequacy of behaviour (Carver \& Scheier, 1998).

The other significant component of self-regulatory processes - apart from goal-orientation - is the control of impulsivity (de Ridder \& de Witt, 2006; Mischel et al., 1998). If the individual wants to attain long-term goals, he/she must have impulsivity under control. Some researchers (Vohs \& Baumeister, 2011) consider this so important that they claim that selfregulation and impulsivity are synonyms. The research revealed that if individuals have problems with controlling impulsivity in their behaviour, they frequently fail to attain their personal goals (Baumeister \& Heatherton, 1996; Baumeister, Heatherton, \& Tice, 1994).

To sum up, there appear two components of self-regulation that play a decisive role in the behaviour of individuals. These are goal-orientation and impulsivity. In consequence, we placed these two components in the centre of the research presented in this paper.

\section{Individual's Characteristics and Self-regulation}

It is well documented that self-regulation is linked to the individual's characteristics that affect the planning and execution of behaviour. Paradoxically, little data is available how these characteristics have been developed in the individual. Most frequently self-regulation has been investigated in self-contained, small or medium-size groups of subjects. Little information has been obtained about self-regulation of behaviour in large samples, in different age groups and groups with varied sociodemographic characteristics, e.g., the level of schooling. Therefore, in order 
to obtain well-grounded empirical data the primary purpose of the research presented in this article was to investigate self-regulation of behaviour in large, representative samples as well as provide data on gender and specific age groups within them.

As concerns the relationship of self-regulation to age of individuals, we respected the proposition of Zeidner, Boekaerts and Pintrich (2000) that "... research needs to carefully look at the development of self-regulatory skills over time. Thus we need to understand how biology and aging (maturation, senescence) change both the self-regulatory processes (goal-setting, monitoring, feedback control, self-evaluation, etc.) and the effects of selfregulatory skills" (p.764).

As concerns gender, a collaborative study of self-regulation skill in France, Germany, and Iceland (Gestsdóttir et al., 2014) revealed that girls outperformed boys only in Iceland. Other independent variables such as parental socioeconomic background (parental education and income) and gender in relationship to self-regulation among children were explored by Størksen et al. (2014). Results indicated that Norwegian girls outperformed boys in individual behavioural regulation (assessed by the Head-ToesKnees-Shoulders task) and classroom behavioural regulation (rated by teachers on the Survey of Early School Adjustment). In addition, parental socioeconomic status related positively to girls' individual behavioural regulation but not to that of boys'.

In this paper we extended the scope of investigation to other individual characteristics besides age and gender. As seen in the objectives section, we concentrated also on the level of education of individuals as related to their self-regulation of behaviour.

\section{Instruments Used in Research on Self-regulation}

Self-regulation has been studied with a number of empirical instruments. The most frequent have been self-rating scales. For instance, Ryan and Connell (1989) developed an entire series of self-regulation questionnaires assessing domain-specific individual differences in motivation and regulation. They concentrated on assessing the regulation of a particular behaviour (e.g., exercising regularly) or class of behaviours (e.g., engaging 


\section{Jakesova et al-SR of Behaviour: Students vs Other Adults}

in religious activities). Each questionnaire asked why the respondent performed a behaviour (or class of behaviours). The reasons of the behaviour were categories to represent different styles of regulation or motivation (Ryan \& Connell, 1989). Questionnaires were developed for each age cohort (late-elementary, middle school children and adults). Academic SelfRegulation Questionnaire (SRQ-A) was developed for assessing selfregulation in academic settings. The questionnaire asks about the reasons why children in late elementary and middle schools do their school work. The comparable SRQ for adults is referred to as the Learning SelfRegulation Questionnaire (SRQ-L).

Another commonly used research tool is Questionnaire on SelfRegulation (QSR) of Bandy and Moore (2010). This questionnaire is used to assess children's ability to regulate negative emotions and disruptive behaviour, and to set and attain goals.

To investigate self-regulation of children and minors who live in institutional care, Vávrová (2015) developed a culture and social-fair instrument, the Self-Regulation Questionnaire in Children and Minors (SRQ-CM). The main effort of the investigation was to clarify the relationship between environmental factors and the level of self-regulation of young people ${ }^{1}$.

There is one specific instrument which concentrates on measuring general (rather than domain-specific) self-regulation of behaviour of subjects. It is the Self-Regulation Questionnaire, originally developed by Brown, Miller, and Lawendowski (1999). This questionnaire is a self-rating device aimed on measuring self-regulation of behaviour in the adult population. In spite of the frequent use of this instrument in previous research, inconclusive results were obtained as concerns its factorial structure (Carey, Neal, \& Collins, 2004; Neal \& Carey, 2005; Potgieter \& Botha, 2009; Vosloo et al., 2013; Dias \& Garcia del Castillo, 2014), which contests its conceptual base. This instrument was used in the research presented in this paper, however, after adaptation and validation in the Czech environment. 


\section{Present Study}

This research has two aims. The primary aim is to obtain data on the selfregulation of behaviour in a large, representative sample of adult subjects. We consider it highly important to have well empirically grounded data on self-regulation and these cannot be received by other means apart from measuring it in a representative sample of the population. Secondly, our aim is to compare the data on the self-regulation of behaviour obtained from the representative adult sample with the data from a specifically selected sample of the population. In this case, the specific sample consists of university students. The choice of this sample was motivated by the idea that university students - due to intensive efforts in learning regulation and systematic training for their future profession - may manifest a higher ability of selfregulation of goal planning and better control of impulses than the representative sample of adults. We assumed that these two samples have different patterns of self-regulation of behaviour due to prevailing daily activities (studying versus job responsibilities) which, in the long run, affects their self-regulation of behaviour in a different degree.

In view of the discussion presented in previous sections, in this study we shall relate the two dimensions of the self-regulation of behaviour (i.e., Goal Orientation and Impulsivity) in two samples (the representative and the student samples) to three variables: gender, age and level of education. We formed the following hypotheses:

H1: The student sample yields a higher score than the representative sample in Goal Orientation.

$\mathrm{H} 2$ : The student sample yields a lower score than the representative sample in Impulsivity (i.e., students better control impulsivity).

H3: In both samples the score on Goal Orientation is higher than that on Impulsivity.

H4: In both samples the score on Goal Orientation of females is higher than that of males.

H5: In both samples the score on Impulsivity in males is lower than that of females (i.e., males better control impulsivity). 
H6: In both samples there is a statistically significant difference among age groups in Goal Orientation scores.

H7: In both samples there is a statistically significant difference among age groups in Impulsivity scores.

H8: In both samples there is a statistically significant difference in Goal Orientation scores according to the level of education.

H9: In both samples there is a statistically significant difference in Impulsivity scores according to the level of education.

\section{Methods}

\section{Participants}

The measurements were conducted in two separate samples. The first sample was the representative sample of the Czech adult population ranging from 15 to 90 year-old with a mean age of 44.8 (S.D. $=16.82$ ). It consisted of 1060 respondents.

The other sample was the student sample. It consisted of 1244 respondents who at the time of the research attended formal or informal university programmes in the region of Zlín in the Czech Republic. The student sample is assumed to well represent the population of university students in the particular Czech location. The age range of the student sample was 19 to 83 years, with the age group of 15-29 year to be proportionally largest $(70 \%)$. The structure of the samples is in Table 1.

\section{Table 1}

The Structure of the samples

\begin{tabular}{llllll}
\hline & & \multicolumn{2}{c}{$\begin{array}{c}\text { Representative } \\
\text { sample }\end{array}$} & \multicolumn{2}{c}{ Student sample } \\
\cline { 3 - 5 } & & $\mathrm{N}$ & $\%$ & $\mathrm{~N}$ & $\%$ \\
\hline \multirow{2}{*}{ Gender } & Male & 507 & 48 & 336 & 27 \\
& Female & 553 & 52 & 905 & 73 \\
& Total & 1060 & 100 & 1241 & 100
\end{tabular}


IJEP - International Journal of Educational Psychology 4(2) 65

Table 1. Continued

\begin{tabular}{llllll}
\hline & & \multicolumn{2}{c}{$\begin{array}{c}\text { Representative } \\
\text { sample }\end{array}$} & \multicolumn{2}{c}{ Student sample } \\
\cline { 3 - 6 } & & $\mathrm{N}$ & $\%$ & $\mathrm{~N}$ & $\%$ \\
\hline Age & $15-29$ & 240 & 23 & 856 & 70 \\
& $30-44$ & 295 & 28 & 178 & 15 \\
& $45-59$ & 255 & 24 & 2 & 0 \\
& $60-90$ & 270 & 25 & 192 & 16 \\
& Total & 1060 & 100 & 1228 & 100 \\
\hline $\begin{array}{l}\text { Level of } \\
\text { education }\end{array}$ & $\begin{array}{l}\text { Lower secondary } \\
\text { (ISCED 244) }\end{array}$ & 143 & 14 & 16 & 1 \\
& $\begin{array}{l}\text { Vocational } \\
\text { (ISCED 353) }\end{array}$ & 435 & 41 & 28 & 2 \\
& $\begin{array}{l}\text { Upper secondary } \\
\text { (ISCED 344) }\end{array}$ & 332 & 31 & 1030 & 83 \\
& $\begin{array}{l}\text { University } \\
\text { Total }\end{array}$ & 150 & 14 & 170 & 14 \\
& & 1060 & 100 & 1244 & 100 \\
\hline
\end{tabular}

\section{Measures}

The measuring tool was the Self-Regulation Questionnaire (SRQ), originally constructed by Brown, Miller and Lawendowski (1999). They based the instrument on the seven-phase model of the process of selfregulation of behaviour developed by Kanfer (1970) and Miller and Brown (1991). Accordingly, the seven dimensions of their instrument correspond to seven phases of the self-regulation process: (1) Attention to information input, (2) Evaluation by comparing oneself to a standard, (3) Willingness to consider change, (4) Engagement in a search for alternatives, (5) Devising a plan of action, (6) Implementing the plan, and (7) Evaluation of the plan. The questionnaire consists of 63 items; short versions of the questionnaire published in other studies varied from 21 to 31 items (Carey, Neal, \& Collins, 2004; Neal \& Carey, 2005; Vosloo et al., 2013).

The instrument uses a five-point interval scale with end points $1=$ strongly disagree and $5=$ strongly agree, to assess statements, e.g., Once $I$ have a goal, I can usually plan how to reach it. It is important to emphasize 
that the questionnaire measures the generic rather than the domain-specific self-regulation capacity of one's behaviour.

The construction validity of SRQ was assessed in two studies (Carey, Neal, \& Collins 2004; Neal \& Carey, 2005) which however did not prove the seven theoretically assumed factors of self-regulation of behaviour. The long form (63 items) and the short form (31 items) were used also in South Africa by Potgieter and Botha (2009) and Vosloo et al. (2013) who confirmed the seven factors, however, their interpretation was different from the original model of SRQ. In the USA, Neal and Carey (2005) proved the two factor model with the dimensions Goal Orientation and Impulsivity, so did Dias and Garcia del Castillo (2014) in Portugal.

The Czech version of the questionnaire was adapted and validated in two rounds. In the first round, it was administered to 360 Czech university students. Four factors appeared to be the best factorial solution: (1) Goal Orientation (i.e., I usually proceed to accomplish my aims); (2) Impulsivity (i.e., I give up easily if facing an obstacle); (3) Self-direction (i.e., I do not notice the effects of my actions until it is too late); (4) Decision Making (i.e., As soon as I see a problem, I start looking for possible solutions). The four factors covered 27 items, which explained $43 \%$ of the total variance, with an Alpha of .88 (Gavora, Jakešová, \& Kalenda, 2015). In the subsequent validation with a larger sample of Czech university students $(n=1139)$ the four factor model, which covered 22 items and explained $44 \%$ of the total variance (Alpha .85), was again confirmed (Jakešová, Kalenda, \& Gavora, 2015). Alphas in the dimensions ranged from .50 to .78; the overall Alpha was .85. After a confirmatory factor analysis one item was excluded because of a low factor loading (.36). The CFA results were as follows: $\mathrm{Chi}^{2}$ ( $\mathrm{df}=$ $178, \mathrm{p}=.00)=65.148, \mathrm{Chi}^{2} / \mathrm{df}=3.873$. GOF indexes: $\mathrm{RMR}=.052$, $\mathrm{RMSEA}=.050, \mathrm{TLI}=.887, \mathrm{CFI}=.904, \mathrm{GFI}=.944, \mathrm{AGFI}=.927, \mathrm{PCLOSE}$ $=.452$ signifying that the model fits the data well.

Because the present research was designed as broad survey administered in two large samples, for practical reasons only two dimensions, Goal Orientation and Impulsivity, were used, each with 4 items (Table 2). The selection of these two dimensions was based on the assumption that (1) they represent the core of the self-regulation capacity; (2) and were confirmed in other studies (Neal \& Carey, 2005; Dias \& Garcia del Castillo, 2014). 
Table 2

Items of ScSRQ-CZ and factor loadings for the representative and the student samples

\begin{tabular}{|c|c|c|c|c|c|}
\hline $\begin{array}{l}\text { Goal } \\
\text { Orientation }\end{array}$ & $\begin{array}{c}\text { Representative } \\
\text { sample }\end{array}$ & $\begin{array}{l}\begin{array}{l}\text { Student } \\
\text { sample }\end{array} \\
\end{array}$ & Impulsivity & $\begin{array}{c}\text { Representative } \\
\text { sample }\end{array}$ & $\begin{array}{l}\text { Student } \\
\text { sample }\end{array}$ \\
\hline $\begin{array}{l}\text { I stick to my } \\
\text { plans if they } \\
\text { work well. }\end{array}$ & .809 & .783 & $\begin{array}{l}\text { I have ideas } \\
\text { but I cannot } \\
\text { decide how } \\
\text { to } \\
\text { accomplish } \\
\text { them. }\end{array}$ & .661 & .670 \\
\hline $\begin{array}{l}\text { I usually } \\
\text { proceed to } \\
\text { achieve my } \\
\text { goals. }\end{array}$ & .753 & .710 & $\begin{array}{l}\text { Even if I } \\
\text { decide to act } \\
\text { according to } \\
\text { a plan, I } \\
\text { have } \\
\text { problems to } \\
\text { accomplish } \\
\text { it. }\end{array}$ & .737 & .647 \\
\hline $\begin{array}{l}\text { I have } \\
\text { personal } \\
\text { standards } \\
\text { which I } \\
\text { observe. }\end{array}$ & .721 & .639 & $\begin{array}{l}\text { I hesitate } \\
\text { when I am } \\
\text { expected to } \\
\text { act. }\end{array}$ & .643 & .648 \\
\hline $\begin{array}{l}\text { I know how I } \\
\text { want to be. }\end{array}$ & .747 & .496 & $\begin{array}{l}\text { I give up } \\
\text { easily if I } \\
\text { come across } \\
\text { an obstacle. }\end{array}$ & .564 & .559 \\
\hline Alphas & .763 & .713 & & .566 & .692 \\
\hline
\end{tabular}

This short version of the instrument will be referred to as ScSRQ-CZ ( $\mathrm{Sc}$ stands for screening). A high score on Goal Orientation assumes better self- 
regulation. Conversely, a low score on Impulsivity supposes a better ability to reduce impulsivity.

The validation of ScSRQ-CZ was performed separately for the student sample and for the representative sample. In the student sample, the Alpha for Goal Orientation was .71 and for Impulsivity it was .69 (total for 4 items), and the total explained variance was $57 \%$. In the representative sample the Alpha in Goal Orientation was .76 and for Impulsivity it was .57 (total for 4 items). The total explained variance was $46 \%$. The two dimensions correlate negatively, as expected: $-.171(\mathrm{p}=.00)$.

The data on the representative sample was gathered by the Stem/Mark Agency (Prague) through individual CAPI (Computer Assisted Personal Interviewing). The data on the student sample was collected by the authors and research assistants. Students filled in the questionnaire in classrooms during their regular courses.

\section{Results}

First, we shall inspect the differences between the samples on both dimensions of ScSRQ-CZ. As presented in Table 3, there was no statistically significant difference between the representative and the student samples on Goal Orientation (Mann-Whitney U-test $\mathrm{Z}=-.919 ; \mathrm{p}=.055$ ). This is in contrast with our hypothesis (H1) which assumed a higher score on Goal Orientation in favour of the student sample. However, the significance level was exceeded only slightly (by .005). This in effect means that the student sample is better in Goal Orientation than the representative sample, however, the difference is small. As concerns Impulsivity, there was no statistically significant difference between the representative and the student samples $(\mathrm{Z}=-.796 ; \mathrm{p}=.426)$. This again is in contrast with the hypothesis $(\mathrm{H} 2)$, because we assumed that students are less emotional and are more detached in self-regulation of behaviour due to the rather easy-going life and open climate in the Czech university environment.

As expected, both samples scored higher on Goal Orientation than on Impulsivity (H3). We assumed a higher score on Goal Orientation because the opposite results would be critical, indicating that one's actions are governed by strong emotions rather than by rational planning and acting. In 
Goal Orientation the score was high, much above the midpoint of the scale (1 - 5), which signifies a very good perceived ability of the respondents to plan actions, set goals and control their accomplishment. Conversely, the low score on Impulsivity indicates a very good ability to control one's impulses when performing actions. While the mean scores on Goal Control of the two samples are almost identical (difference of .099), on Impulsivity the difference is somewhat larger (.678), but still negligible. In Impulsivity the median is the same in both samples.

\section{Table 3}

Descriptive data on $S c S R Q-C Z$ of the representative and the student samples Representative Sample Student Sample

\begin{tabular}{lccccccccc} 
Dimensions & $\mathrm{N}$ & Mean & Median & S.D. & $\mathrm{N}$ & Mean & Median & S.D. & $\mathrm{p}$ \\
\hline Goal & 1060 & 4.01 & 4.00 & .81 & 1242 & 4.10 & 4.25 & .66 & .055 \\
$\begin{array}{l}\text { Orientation } \\
\text { Impulsivity }\end{array}$ & 1060 & 2.76 & 2.75 & .75 & 1241 & 2.80 & 2.75 & .79 & .426 \\
\hline
\end{tabular}

As concerns gender, we expected higher scores of females on Goal Orientation (H4) and, conversely, lower scores on Impulsivity in males in both samples (H5). The assumption that males better manage impulses was based on the notion that they are generally less emotional and less anxious. On the other hand, females were supposed to be more stable in setting their goals of personal actions and are more reliable in their accomplishment. As Table 4 shows these assumptions were not completely confirmed. In Goal Orientation there was a statistically significant difference in favour of females only in the student sample, whereas in the representative sample no statistically significant difference was proven. In Impulsivity males had statistically lower scores in both samples thus demonstrating that they are less impulsive and can better control their emotions. H5 was confirmed in both samples. 
70 Jakesova et al-SR of Behaviour: Students vs Other Adults

Table 4

Gender differences in ScSRQ-CZ of the representative and the student samples

\begin{tabular}{|c|c|c|c|c|c|c|c|c|c|}
\hline \multirow[b]{2}{*}{ Dimension } & \multicolumn{5}{|c|}{ Representative Sample } & \multicolumn{4}{|c|}{ Student Sample } \\
\hline & Gender & $\mathrm{N}$ & Mean & S.D. & Sign. & $\mathrm{n}$ & Mean & S.D. & Sign. \\
\hline Goal & Male & 507 & 4.03 & .76 & & 333 & 4.02 & .72 & \\
\hline Orientation & Female & 553 & 3.98 & .86 & .131 & 909 & 4.13 & .63 & .044 \\
\hline Imn & Male & 507 & 2.67 & .75 & & 332 & 2.65 & .81 & \\
\hline impuisivity & Female & 553 & 2.85 & .75 & & 903 & 2.86 & .78 & \\
\hline
\end{tabular}

As concerns the age, we hypothesized that in Goal Orientation there would be statistical differences among the age groups (H6). This hypothesis was confirmed in both samples $(\mathrm{p}=.015 ; \mathrm{p}=.000$, respectively). A close look at Table 5 reveals that the mean scores rise with age (with the exception of the oldest age group in the student sample). This suggests that the experiences that one accumulates in the course of life may contribute to the improvement of goal planning and its accomplishment.

Regarding Impulsivity, we also hypothesized statistical differences among age groups (H7). However, the hypothesis was confirmed only in the student sample $(\mathrm{p}=.000)$. Conversely to Goal Orientation, we assumed that the scores on Impulsivity would drop with age. We expected that life experiences contribute to the development of a higher ability to balance emotions in older ages. This assumption did not prove. The findings about the relationship of self-regulation of behaviour to age groups, however, must be taken cautiously because of the uneven number of respondents in the individual age groups, especially in the student sample. For instance, in the age group 45-59 years, there were only two respondents and the age span for the oldest groups in both samples was 30 years (Table 1). 
Table 5

Age differences in the representative and the student samples

\begin{tabular}{lllllllll}
\hline & \multicolumn{3}{c}{$\begin{array}{l}\text { Representative Sample } \\
\text { Goal } \\
\text { Orientation }\end{array}$} & \multicolumn{3}{c}{ Impulsivity } & \multicolumn{3}{c}{$\begin{array}{l}\text { Soal } \\
\text { Godudent Sample }\end{array}$} \\
\cline { 2 - 9 } Oge & Mean & S.D. & Mean & S.D. & Mean & S.D. & Mean & S.D. \\
\hline $15-29$ & 3.91 & .79 & 2.73 & .70 & 4.05 & .66 & 2.86 & .78 \\
$30-44$ & 3.99 & .82 & 2.78 & .74 & 4.26 & .65 & 2.54 & .75 \\
$45-59$ & 4.06 & .76 & 2.79 & .79 & 4.88 & 1.77 & 2.00 & .35 \\
$60+$ & 4.07 & .88 & 2.77 & .80 & 4.22 & .64 & 2.84 & .85 \\
\hline $\mathrm{p}$ & $\mathbf{. 0 1 5}$ & & .664 & & $\mathbf{. 0 0 0}$ & & $\mathbf{. 0 0 0}$ & \\
\hline
\end{tabular}

The level of education of respondents was believed to be a strong variable that affects the level of self-regulation of behaviour. We assumed that the higher the levels of education, the better scores are achieved on Goal Orientation, and conversely, lower scores on Impulsivity. These assumptions were not confirmed in full. There was no statistically significant difference in Goal Orientation both in the representative sample $\left(\mathrm{Chi}^{2}=4.75, \mathrm{df}=3\right.$, $\mathrm{p}=.191)$ and the student sample $\left(\mathrm{Chi}^{2}=3.59, \mathrm{df}=5, \mathrm{p}=.610\right)$. Thus $\mathrm{H} 8$ was disproved. As concerns Impulsivity, in both samples the hypothesis (H9) was confirmed. Respondents with university degrees better control their impulsivity, and vice versa, respondents with lower education are more impulsive (the representative sample $\mathrm{Chi}^{2}=21.58 ; \mathrm{df}=3, \mathrm{p}=.000$; the student sample $\mathrm{Chi}^{2}=20.85, \mathrm{df}=2, \mathrm{p}=.000$ ).

Overall, the level of education of respondents proved to be an important factor which distinguishes those with high and low impulsivity. People who have higher education seem to be more cautious and deliberate than those with lower education. As concerns Goal Orientation, the same relationship is not true. This shows that goal setting, monitoring and achieving has different relationships to the level of education; or to put it differently, a given level of education is not necessarily a factor that precludes a different goal-related behaviour of respondents. 


\section{Jakesova et al-SR of Behaviour: Students vs Other Adults}

\section{Discussion}

In this research we used a self-rating questionnaire to assess selfregulation of adults and university students in two large samples in the Czech Republic. While the students are also adults in the demographical sense, we claimed that they have specific self-regulation characteristics which we assumed to be different from those of adults in the representative sample of the Czech population. This hypothesis was not confirmed as concerns the mean scores both on Goal Orientation and Impulsivity. The two samples yielded similar mean scores in both dimensions, while the score on Goal Orientation was much higher than on Impulsivity.

These findings are important for three reasons. (1) We have evidence that the two components of self-regulation of behaviour are similar in two large and demographically varied samples in the same country. This strengthens our knowledge of how Goal Orientation and Impulsivity abilities are conceived in populations. (2) In contrast to other research on self-regulation of behaviour, which has been most frequently conducted with smaller samples and with samples of a specific section of the population (most typically with university students), the advantage of this study is in the large samples of respondents, of which one was representative, which guarantees that few uncontrolled factors came into play. (3) The findings support the stability of data received with the self-rating instrument ScSRQ-CZ that we used with the two samples.

Apart from these findings, we received evidence of the contrasting character of Goal Orientation and Impulsivity. They are both important in self-regulation of behaviour, however, in an inverse direction. Goal setting, monitoring, control and achieving require a certain level of emotional investment, but not in such a manner and style that it interferes with goal performance. Lack of impulsivity is such unfavourable characteristic.

As concerns gender, no statistical difference was found between females and males in Goal Orientation in the representative sample. This supports, in fact, the strengths of the findings of the entire representative population. In the student sample, females were superior to males in Goal Orientation. However the size of the female's subsample was three times larger than that 
of males. This discrepancy might cause fluctuations that affected the results of the males' subsample.

Age was assumed to be a factor that affects self-regulation of behaviour ability. We confirmed differences among age groups in Goal Orientation in both samples. As we have explained, experiences which people accumulate in the course of life may contribute to the improvement of goal planning and their accomplishment. Thus, age differences plausibly reflect these tendencies. The level of education proved to be an important factor which distinguishes those with high and low impulsivity rather than goal orientation.

Overall, the demographic variables that we investigated aid in the understanding of the phenomenon of the ability to self-regulate one's behaviour. Gender, age, and the level of education are important variables that affect the complexity of self-regulation. However, more research must be conducted that would clarify the functioning of these variables in more detail.

It should be noted that self-regulation ability has been most typically investigated in specific domains (for instance, in academic learning or health related behaviour). Our attempt differed from these studies by taking into account the generic ability of self-regulation of behaviour. In other words, we attempted to capture a more general, across the domain, strand of selfregulation. Thus the results have broader usage and application.

It should also be noted that we did not concentrate on self-regulated behaviour per se, that is, in real life situations; rather, we gathered data on how respondents conceived their abilities in such behaviour. Conceiving self-regulation is in common with one's conceptualisation of self-regulation and with one's beliefs in potentials in goal performance and the control of impulsivity. Research into real-life self-regulation requires other methodological devices, the observation of performance, first of all, which we were unable to accomplish at this point in our research endeavours. 
74 Jakesova et al-SR of Behaviour: Students vs Other Adults

\section{References}

Austin, J. T., \& Vancouver, J. B. (1996). Goal Constructs in Psychology: Structures, Process, and Context. Psychological Bulletin, 120, 338-375. doi: 10.1037/0033-2909.120.3.338

Bandy, T., \& Moore, K. (2010). Assessing self-regulation: A guide for outof-school time program practitioners. Washington, D.C.: Child Trends. Baumeister, R. F., \& Heatherton, T. F. (1996). Self-Regulation Failure: An overview. Psychological Inquiry, 7, 1-15. doi: 10.1207/s15327965pli0701_1

Baumeister, R. F., Heatherton, T. F., \& Tice, D. M. (1994). Losing Control: Why people fail at self-regulation. San Diego: Academic Press.

Brown, J. M., Miller, W. R., \& Lawendowski, L. A. (1999). The Selfregulation Questionnaire. In L. Vandecreek, L., \& T. L. Jackson (Eds.), Innovations in Clinical Practice: A Sourcebook, vol. 17 (pp. 281-292). Sarasota, FL: Professional Resource Press/Professional Resource Exchange.

Cameron, L. D., \& Leventhal, H. (2003). Self-Regulation, health and illness: An overview. In L. D. Cameron, \& H. Leventhal (Eds.), Self-regulation of Health and illness behaviour (pp. 1-13). London: Routledge.

Carey, K. B., Neal, D. J., \& Collins, S. E. (2004). A psychometric analysis of the Self-Regulation Questionnaire. Addictive Behaviors, 29, 253-260. doi: 10.1016/j.addbeh.2003.08.001

Carey, M. P., Carey, K. B., Carnrike Jr., C. L. M., \& Meisler, A. W. (1990). Learned resourcefulness, drinking, and smoking in young adults. Journal of Psychology, 124, 391-395. doi: 10.1080/00223980.1990.10543233

Carver, C. S. (2004). Negative affects deriving from the behavioral approach system. Emotion, 4, 3-22. doi: 10.1037/1528-3542.4.1.3

Carver, C. S., \& Scheier, M. F. (1982). Control theory: A useful conceptual framework for personality - social, clinical, and health psychology. Psychological Bulletin, 92, 111-135. doi: 10.1037/0033-2909.92.1.111

Carver, C. S., \& Scheier, M. F. (1998). On the self-regulation of behaviour. New York: Cambridge University Press. 
Carver, Ch. S., \& Scheier, M. F. (2002). Control processes and selforganization as complementary principles underlying behaviour. Personality and Social Psychology Review, 6(4), 304-315. doi: 10.1207/S15327957PSPR0604_05

Carver, C. S., \& Scheier, M. F. (2011). Self-Regulation of Action and Affect. In K. Vohs, \& R. F. Baumeister (Eds.), Handbook of SelfRegulation: Research, Theory, and Applications (pp. 3-21). New York: The Guilford Press.

Chassin, L., \& DeLucia, C. (1996). Drinking during adolescence. Alcohol Health and Research World, 20, 175-180.

de Ritter, D., \& de Witt, J. (Eds.). (2006). Self-regulation in Health Behavior. Chichester: John Willey.

Dias, P., \& Garcia del Castillo, J. A. (2014). Self-regulation and Tobacco Use: Contributes of the Confirmatory Factor Analysis of the Portuguese Version of the Short Self-Regulation Questionnaire. Procedia - Social and Behavioral Sciences, 159, 370-374. doi: 10.1016/j.sbspro.2014.12.390

Duckworth, A. L., Quinn, P. D., \& Tsukayama, E. (2012). What No Child Left Behind leaves behind: The roles of IQ and self-control in predicting standardized achievement test scores and report card. Journal of Educational Psychology, 104, 439-451. doi: $10.1037 / \mathrm{a} 0026280$

Duckworth, A. L., \& Carlson, S. M. (2015). Self-regulation and school success. In B. W. Sokol, F. M. E. Grouzet, \& U. Müller (Eds.), Selfregulation and autonomy: Social and developmental dimensions of human conduct (pp. 208-230). New York: Cambridge University Press. Eerde, V. W. (2000). Procrastination: Self-regulation in initiating aversive goals. Applied Psychology: An International Review, 49(3), 372-389. doi: 10.1111/1464-0597.00021

Elliott, A. J. (Eds.). (2008). Handbook of approach and avoidance motivation. Mahwah: Erlbaum.

Gavora, P., Jakešová, J., \& Kalenda, J. (2015). The Czech Validation of Self-Regulation Questionnaire. Procedia - Social and Behavioral Sciences, 171, 222-230. doi: 10.1016/j.sbspro.2015.01.113 
Gestsdóttir, S., Von Suchodoletz, A., Wanless, S. B., Hubert, B., Guimard, P., Birgisdóttir, F., Gunzenhauser, C., \& McClelland, M. (2014). Early behavioral self-regulation, academic achievement, and gender: Longitudinal findings from France, Germany, and Iceland. Applied Developmental Science, 18(2), 90-102. doi: 10.1080/10888691.2014.894870

Hoyle, R. H. (Eds.). (2010). Handbook of Personality and Self-Regulation. Chichester: John Wiley.

Human-Vogel, S. (2006). Students' mental models of positive mood and self-regulation in learning. South African Journal of Psychology, 36(3), 613-633. doi: 10.1177/008124630603600311

Jakešová, J., Kalenda, J, \& Gavora, P. (2015). Self-regulation and Academic Self-efficacy of Czech University Students. Procedia - Social and Behavioral Sciences, 174, 1117-1123. doi: 10.1016/j.sbspro.2015.01.803

Kanfer, F. H. (1970). Self-regulation: Research, issues, and speculations. In C. Neuringer, \& J. L. Michael (Eds.), Behavior modification in clinical psychology (pp. 178-220). New York: Appleton-Century-Crofts.

Miller, W. R., \& Brown, J. M. (1991). Self-regulation as a conceptual basis for the prevention and treatment of addictive behaviors. In N. Heather, W. R. Miller, \& J. Greeley (Eds.), Self-control and the addictive behaviours (pp. 3-79). Sydney: Maxwell Macmillan.

Mischel, W., Cantor, N., \& Feldman S. (1998). Principles of Self-regulation: The nature of willpower and self-control. In E. T. Higgins, \& A. E. Kruglanski (Eds.), Social Psychology: Handbook of Principles (pp. 329-360). New York: Guilford.

Motiea, H., Heidaria, M., \& Sadeghic, M. A. (2012). Predicting academic procrastination during self-regulated learning in Iranian first grade high school students. Procedia - Social and Behavioural Sciences, 69(1), 2299-2308. doi:10.1016/j.sbspro.2013.02.023

Neal, D. J., \& Carey, K. B. (2005). A Follow-Up Psychometric Analysis of the Self-Regulation Questionnaire. Psychology of Addict. Behavior, 14, 414-422. doi: 10.1037/0893-164X.19.4.414

Nota, L., Soresi, S., \& Zimmerman, B. J. (2004). Self-regulation and academic achievement and resilience: A longitudinal study. 


\section{IJEP - International Journal of Educational Psychology 4(2) 77}

International Journal of Educational Research, 41(3), 198-215. doi: 10.1016/j.ijer.2005.07.001

Potgieter, J. C., \& Botha, K. F. H. (2009). Psychometric properties of the Short Self-Regulation Questionnaire (SSRQ) in a South African context. Journal of Psychology in Africa, 3, 321-328. doi: 10.4102/sajip.v39i1.1157

Ryan, R. M., \& Connell, J. P. (1989). Perceived locus of causality and internalization: Examining reasons for acting in two domains. Journal of Personality and Social Psychology, 57, 749-761.

Schunk, D. H., \& Zimmerman, B. J. (1998). Self-Regulated Learning: From Teaching to Self-Reflective Practice. New York: Guilford Press.

Schwarzer, R. (2001). Social-Cognitive Factors in Changing Health-Related Behavior. Current Directions in Psychological Science, 10(2), 47-51. doi: 10.1111/1467-8721.00112

Senécal, C., \& Vallerand, R. J. (1995). Self-regulation and academic procrastination. The Journal of Social Psychology, 135(5), 607-619. doi: 10.1080/00224545.1995.9712234

Størksen, I., Ellingsen, I. T., Wanless, S. B., \& McClelland, M. M. (2014). The influence of parental socioeconomic background and gender on self-regulation among 5-year-old children in Norway. Early Education and Development, 1-22. doi: 10.1080/10409289.2014.932238

Vávrová, S. (2015). Children and minors in institutional care: Research of self-regulation. Procedia - Social and Behavioral Sciences, 171, 14341441. doi: 10.1016/j.sbspro.2015.01.265

Vávrová, S., \& Gavora, P. (2014). Comparison of self-regulation in children and adolescents in children's home and protective educational facility clarifies. Procedia - Social and Behavioral Sciences, 174, 2524-2531. doi: 10.1016/j.sbspro.2015.01.926

Veenstra, R, Lindenberg, S. Tinga, F., \& Ormel, J. (2010). Truancy in late elementary and early secondary education: The influence of social bonds and self-control - the TRAILS study. International Journal of Behavioural Development, 34(4), 302-310. doi: 10.1177/0165025409347987

Vohs, K., \& Baumeister, R. F. (Eds.). (2011). Handbook of Self-Regulation: Research, Theory, and Applications. New York: The Guilford Press. 
Vosloo, M., Potgieter, J., Temane, M., Ellis, S., \& Khumalo, T. (2013). Validation of the Short Self-Regulation Questionnaire in a Group of Black Teachers: The SABPA study. South African Journal of Industrial Psychology, 1, 1-10. doi:10.4102/sajip.v39i1.1157

Wills, T. A., Sandy, J. M., \& Yaeger, A. M. (2002). Moderators of the relation between substance use level and problems: Test of a selfregulation model in middle adolescence. Journal of Abnormal Psychology, 111(1), 3-21. doi: 10.1037//0021-843X.111.1.3

Wrosch, C., Scheier, M. F., Carver, Ch. S., \& Schulz, R. (2003). The importance of goal disengagement in adaptive self-regulation: When giving up is beneficial. Self and Identity, 2, 1-20. doi: 10.1080/15298860309021

Zeidner, M., Boekaerts, M., \& Pintrich, P. R. (2000). Self-Regulation: Directions and Challenges for the Future. In M. Boekaerts, P. R. Pintrich, \& M. Zeidner (Eds.), Handbook of Self-Regulation (pp. 750768). San Diego: Academic Press.

Zimmerman, B. J. (2000). Attaining Self-Regulation: A Social Cognitive Perspective. In M. Boekaerts, P. R. Pintrich, \& M. Zeidner (Eds.), Handbook of Self-Regulation (pp. 13-39). San Diego: Academic Press.

\section{Notes}

Note 1. Apart from quantitative studies on self-regulation conducted with questionnaires, there is a number of investigations based on qualitative methods, e.g., on "construct pairing" (Human-Vogel, 2006) or focus group interviews (Vávrová \& Gavora, 2014; Vávrová, 2015). 
IJEP - International Journal of Educational Psychology 4(2) 79

Jitka Jakesova is researcher at the Research Center of FHS at Tomas Bata University in Zlín, Czech Republic.

Peter Gavora is researcher at the Research Center of FHS at Tomas Bata University in Zlín, Czech Republic.

Jan Kalenda is researcher at the Research Center of FHS at Tomas Bata University in Zlín, Czech Republic.

Contact Address: Research Centre, Faculty of Humanities nám. T. G. Masaryka 1279. 76001 Zlín Jakesova’s email: jjakesova@fhs.utb.cz 